\title{
Kapasitas Dan Akuntabilitas Perangkat Desa Dalam Pengelolaan Dana Desa Di Desa Osango Kecamatan Mamasa Kabupaten Mamasa
}

\author{
Rivai Makduani \\ Institut Agama Islam DDI Polewali Mandar \\ Jl. Gatot Soebroto Kelurahan Madatte Kecamatan Polewali Kab. Polewali Mandar
}

\begin{abstract}
ABSTRAK
Penelitian ini merupakan penelitian deskriptif dengan pendekatan kuantitatif yang bertujuan untuk mengetahui kapasitas perangkat desa dan akuntabilitas perangkat desa dalam pengelolaan dana desa di Desa Osango Kecamatan Mamasa Kabupaten Mamasa. Populasi dalam penelitian ini adalah serluruh perangkat desa di Desa Osango Kecamatan Mamasa Kabupaten Mamasa yang berjumlah 30 orang. Metode pemilihan sampel yang digunakan pada penelitian ini adalah metode sensus atau sampling jenuh, sehingga sampel sebagai sumber data dalam penelitian ini berjumlah 30 orang. Metode pengumpulan data yang digunakan adalah metode kuesioner, wawancara, dan dokumentasi. Data yang terkumpul dianalisis secara deskriptif dengan pendekatan analisis kuantitatif.

Hasil analisis memberikan gambaran bahwa kapasitas perangkat desa dalam pengelolaan dana desa di Desa Osango Kecamatan Mamasa Kabupaten Mamasa mencapai persentase sebesar $70,33 \%$ yang berarti bahwa perangkat desa telah memiliki kapasitas yang cukup tinggi atau berkategori sedang dalam pengelolaan dana desa di Desa Osango. Akuntabilitas perangkat desa dalam pengelolaan dana desa di Desa Osango Kecamatan Mamasa Kabupaten Mamasa mencapai persentase sebesar 71,67\% yang berarti bahwa perangkat desa telah cukup akuntabel dalam pengelolaan dana desa di Desa Osango Kecamatan Mamasa Kabupaten Mamasa dan dapat dikatakan bahwa akuntabilitas perangkat desa dalam pengelolaan dana desa di Desa Osango telah cukup sesuai dengan Permendagri No. 113 Tahun 2014 Tentang Pengelolaan Keuangan Desa. Hal ini dapat dilihat dari proses perencanaan, pelaksanaan, penatausahaan, pelaporan dan pertanggung jawaban yang dilakukan oleh perangkat Desa Osango Kecamatan Mamasa Kabupaten Mamasa yang semuanya cukup akuntabel.
\end{abstract}

Kata Kunci: Kapasitas, Akuntabilitas, Pengelolaan Dana Desa

\section{PENDAHULUAN}

\section{A. Latar Belakang Masalah}

Pada hakekatnya tujuan pembangunan Negara Indonesia adalah untuk mensejahterakan masyarakat Indonesia. Dalam Pembukaan Undang-Undang Dasar 1945 dinyatakan bahwa tujuan Pembangunan Nasional Bangsa Indonesia adalah melindugi segenap bangsa dan seluruh tumpah darah Indonesia, memajukan kesejahteraan umum, mencerdaskan kehidupan bangsa, serta ikut melaksanakan ketertiban dunia. Untuk mewujudkan tujuan tersebut dilaksanakan pembangunan nasional, yaitu pembangunan manusia Indonesia seutuhnya dan pembangunan masyarakat seluruhnya. 
Dalam era otonomi sekarang ini, pembangunan desa perlu menjadi prioritas mengingat desa memiliki karakteristik permasalahan yang selalu membelit desa dan cenderung telah menjadi stigma bagi desa, misalnya: (1) Desa memiliki APBDesa yang kecil dan sumber pendapatannya sangat tergantung pada bantuan yang sangat kecil pula; (2) kesejahteraan masyarakat desa rendah sehingga susah bagi Desa mempunyai Pendapatan Asli Desa (PADesa) yang tinggi; (3) masalah itu diikuti oleh rendahnya dana operasional Desa untuk menjalankan pelayanan; dan (4) banyak program pembangunan masuk ke desa, tetapi hanya sebagian kecil yang melibatkan masyarakat.

Lahirnya Undang-Undang Nomor 6 Tahun 2014 tentang Desa merupakan babak baru dalam tata pemerintahan yang memberikan kewenangan dan kepercayaan lebih besar pada pemerintahan desa untuk melaksanakan pembangunan. Selain itu, Undang-Undang Nomor 6 Tahun 2014 tentang Desa membawa misi utama bahwa negara wajib melindungi dan memberdayakan desa agar menjadi kuat, maju, mandiri dan demokratis sehingga dapat menciptakan landasan yang kuat dalam melaksanakan pemerintahan.

Pada hakikatnya Undang-Undang Desa memiliki visi dan rekayasa yang memberikan kewenangan luas kepada desa di bidang penyelenggaraan pemerintahan desa, pelaksanaan pembangunan desa, pembinaan kemasyarakatan desa, dan pemberdayaan masyarakat desa berdasarkan prakarsa masyarakat, hak asal usul, dan adat istiadat desa (Sujarweni, 2015: 102).

Kebijakan tata kelola desa yang dimuat dalam Undang-Undang Desa ini dianggap sebagai kebijakan yang membawa harapan baru dalam upaya meningkatkan kesejahteraan masyarakat desa. Kebijakan tersebut diantaranya adalah alokasi anggaran yang besar kepada desa yang dimaksudkan untuk meningkatkan anggaran desa dalam pembangunan, pelayanan, pembinaan dan pemberdayaan masyarakat desa. Adanya penghasilan tetap dan tunjangan yang diberikan kepada kepala desa beserta perangkatnya diharapkan dapat meningkatkan pelayanan kepada seluruh masyarakat desa. UndangUndang Desa tersebut juga memberi jaminan yang lebih pasti bahwa setiap desa akan menerima dana dari pemerintah melalui anggaran negara dan daerah yang jumlahnya berlipat, jauh di atas jumlah yang selama ini tersedia dalam anggaran desa.

Dalam Undang-Undang Nomor 6 Tahun 2014 tentang Desa pada Pasal 96 disebutkan bahwa pemerintah daerah kabupaten/kota mengalokasikan Alokasi Dana Desa (ADD) dalam APBD kabupaten/kota setiap tahun anggaran. ADD yang berasal dari APBD Kabupaten/Kota tersebut bersumber dari bagian Dana Perimbangan Keuangan Pusat dan Daerah yang diterima oleh Kabupaten/Kota untuk Desa paling sedikit 10\% (sepuluh persen) setelah dikurangi belanja pegawai. Berdasarkan Peraturan Pemerintah No.43 tahun 2014, formulasi perhitungan alokasi dana desa adalah minimal 10\% dari dana transfer pusat ke daerah dikurangi Dana Alokasi Khusus yang disingkat DAK (Irma, 2015: 57).

Anggaran yang bersumber dari APBN yang mengalir ke kas desa terbagi ke dalam 2 (dua) mekanisme penyaluran, yaitu dana transfer ke daerah (on top) secara bertahap yang dikenal dengan Dana Desa (DD) dan mekanisme dana transfer melalui APBD kabupaten/kota yang dialokasikan sebesar 10\% oleh pemerintah daerah untuk disalurkan ke kas desa secara bertahap yang dikenal dengan Alokasi Dana Desa yang disingkat ADD (Kementrian Keuangan Republik Indonesia, 2015: 73). 
Alokasi Dana Desa (ADD) yang ada selanjutnya dikelolah oleh pemerintah desa dengan ketentuaan penggunaan sesuai dengan Peraturan Pemerintah No.72 tahun 2005 tentang desa yang kemudian diatur lebih detail dalam Permendagri No.37 tahun 2007 mengenai tujuan ADD, tata cara perhitungan besaran anggaran per desa, mekanisme penyaluran, penggunaan dana sampai dengan pertanggung jawabannya. Dengan ditetapkan Undang-Undang Desa, prinsip pelaksanaan ADD semakin diperkuat melalaui Peraturan Pemerintah No. 43 Tahun 2014 tentang dana desa yang mengatur mekanisme pelaksanaan ADD dan juga pengalokasiannya.

Kebijakan alokasi anggaran yang besar ini memiliki konsekuensi terhadap pengelolaannya yang seharusnya dilaksanakan secara professional, efektif, efisien, serta akuntabel yang didasarkan pada prinsip-prinsip manajemen publik yang baik agar terhindarkan dari resiko terjadinya penyimpangan, penyelewengan dan korupsi. Pengelolaan keuangan desa pada dasarnya mengikuti pola pengelolaan keuangan daerah dimana Kepala Desa merupakan pemegang kekuasaan pengelolaan keuangan desa. Pendapatan, belanja dan pembiayaan desa harus ditetapkan dalam Anggaran Pendapatan dan Belanja (APB) Desa yang ditetapkan dalam peraturan desa oleh Kepala Desa bersama Badan Permusyawaratan Desa yang disingkat BPD (Sujarweni, 2015: 106).

Anggaran dana desa yang mencapai Rp. 20,7 Triliun yang akan digelontorkan oleh pemerintah pusat sebagai implikasi dari lahirnya UU tentang Desa ini dinilai rawan korupsi dan dapat menyeret para kepala desa ke penjara. Dengan variatifnya karakteristik desa, kapasitas perangkat desa dan regulasi yang relatif baru, diduga terdapat cukup banyak potensi penyelewengan dalam tiap tahapan pengelolaan dana desa, mulai dari proses perencanaan hingga tahap monitoring dan evaluasi. Berdasarkan hasil temuan LSM Jaringan Paralegal Indonesia (JPI), sebagian kasus korupsi di tingkat desa bukan karena niat kejahatan kepala desa, melainkan karena ketidakpahaman para kepala desa dalam memanfaatkan anggaran dan kurangnya kapasitas perangkat desa dalam pengelolaan dana desa (Hamzah, 2015: 42).

Dalam melakukan pekerjaan (aktivitas), rendahnya produktivitas kerja bagi seorang perangkat desa menjadi fenomena sosial yang terjadi di Indonesia belakangan ini. Banyak faktor yang menjadi penyebab, salah satunya adalah manajemen Kepala Desa dan kapasitas atau kemampuan kerja dari perangkat desa itu sendiri. Walaupun pemerintah secara terus menerus telah mendorong peningkatan manajemen dan kapasitas perangkat desa melalui kesempatan meneruskan pendidikan dan pelatihan, baik yang diselenggarakan oleh pemerintah maupun swadaya sendiri oleh perangkat desa tersebut.

Masih banyaknya fenomena laporan keuangan pemerintah termasuk pemerintah desa yang belum menyajikan data-data yang sesuai dengan peraturan dan masih banyak penyimpanganpenyimpangan yang berhasil ditemukan oleh Badan Pemeriksa Keuangan (BPK) dalam pelaksanaan audit laporan keuangan pemerintah membuat tuntutan masyarakat terhadap penyelenggaraan pemerintahan yang baik (good governance government) meningkat. Hal itu juga yang telah mendorong pemerintah pusat dan pemerintah daerah untuk menerapkan akuntabilitas publik.

Akuntabilitas dapat diartikan sebagai bentuk kewajiban mempertanggung jawabkan keberhasilan atau kegagalan pelaksanaan misi organisasi dalam mencapai tujuan dan sasaran yang telah ditetapkan sebelumnya, melalui suatu media pertanggungjawaban yang dilaksanakan secara periodik (Stanbury dalam Mardiasmo, 2013: 20). 
Sebagai salah satu bentuk pertanggungjawaban dalam penyelenggaraan pemerintahan yang diatur dalam Undang-Undang Nomor 17 Tahun 2003 tentang Keuangan Negara dan Undang-Undang Nomor 23 Tahun 2014 tentang Pemerintahan Daerah, upaya konkrit untuk mewujudkan transparansi dan akuntabilitas pengelolaan keuangan pemerintah, baik pemerintah pusat maupun pemerintah daerah adalah dengan menyampaikan laporan pertanggungjawaban berupa laporan keuangan. Laporan keuangan pemerintah yang dihasilkan harus memenuhi prinsip-prinsip tepat waktu dan disusun dengan mengikuti Standar Akuntansi Pemerintahan sesuai dengan Peraturan Pemerintah Nomor 24 Tahun 2005 tentang Standar Akuntansi Pemerintahan.

Pengelolaan keuangan pemerintah daerah termasuk pemerintah desa harus dilakukan berdasarkan tata kelola kepemerintahan yang baik (good governance government), yaitu pengelolaan keuangan yang dilakukan secara transparan dan akuntabel, yang memungkinkan para pemakai laporan keuangan untuk dapat mengakses informasi tentang hasil yang dicapai dalam penyelenggaraan pemerintahan daerah. Oleh karena itu, informasi yang terdapat di dalam Laporan Keuangan Pemerintah Daerah (LKPD) harus bermanfaat dan sesuai dengan kebutuhan para pemakai.

Menurut Forum Dosen Akuntansi Sektor Publik dalam Indriasari dan Ertambang (2014: 21) bahwa salah satu faktor yang mempengaruhi akuntabilitas pelaporan keuangan pemerintah daerah adalah kapasitas sumber daya manusia (SDM) yang melaksanakan sistem akuntansi. Kebijakan untuk melakukan aktivitas tersebut tidak dapat dilakukan oleh orang yang tidak memiliki pengetahuan di bidang akuntansi. Sehingga untuk dapat menghasilkan laporan keuangan yang berkualitas, maka kapasitas SDM yang melaksanakan sistem akuntansi sangatlah penting.

Peraturan Menteri Dalam Negeri Nomor 113 Tahun 2014 tentang Pedoman Pengelolaan Keuangan Desa diharapkan dapat menjadi pedoman dalam pengelolaan keuangan desa karena di dalamnya telah mencakup berbagai prosedur pengelolaan keuangan desa mulai dari perencanaan, pelaksanaan, penatausahaan, pelaporan sampai dengan pertanggungjawaban. Disamping itu, Permendagri No. 113 Tahun 2014 ini mengharuskan agar pengelolaan keuangan desa dilakukan secara transparan, akuntabel dan partisipatif serta tertib dan disiplin anggaran.

Desa Osango Kecamatan Mamasa Kabupaten Mamasa merupakan salah satu desa yang mulai pada tahun 2015 sampai tahun 2019 telah memperoleh anggaran dana desa dari pemerintah pusat. Anggaran dana desa yang diterima oleh Desa Osango Kecamatan Mamasa Kabupaten Mamasa pada tahun 2019 diperoleh melalui tiga tahap penyaluran, yaitu tahap I pada bulan April sebesar 40\% atau sekitar Rp. 700.502.986, tahap II pada bulan Agustus sebesar 40\% atau sekitar Rp. 700.502.986, dan tahap III pada bulan Desember sebesar 20\% atau sekitar Rp. 350.251 .493 sehingga total keseluruhan anggaran yang dikelola oleh pemerintah Desa Osango Kecamatan Mamasa Kabupaten Mamasa pada tahun 2019 adalah sebesar Rp. 1.751.257.465 (LPJ Desa Osango, 2019).

Anggaran desa yang diperoleh oleh pemerintah Desa Osango Kecamatan Mamasa Kabupaten Mamasa yang cukup besar tersebut tentunya membutuhkan pengelolaan yang baik agar tidak terjadi penyelewengan. Dengan demikian, diperlukan peran perangkat desa dengan kapasitas yang memadai untuk membantu kepala desa dalam mengelola dana desa yang cukup besar tersebut. Hal ini perlu dilakukan karena mengingat bahwa dalam hal pengelolaan dana desa, tidak menutup kemungkinan adanya risiko terjadinya kesalahan baik bersifat administratif maupun substantif yang dapat mengakibatkan terjadinya permasalahan hukum karena belum memadainya kapasitas kepala desa dan 
perangkat desa di Desa Osango Kecamatan Mamasa Kabupaten Mamasa dalam hal penatausahaan, pelaporan, dan pertanggungjawaban hasil pengelolaan keuangan desa.

Berdasarkan uraian pada latar belakang masalah tersebut, maka penulis tertarik untuk mengangkat ke dalam kajian ilmiah melalui suatu penelitian dengan judul "Kapasitas dan Akuntabilitas Perangkat Desa Dalam Pengelolaan Dana Desa Di Desa Osango Kecamatan Mamasa Kabupaten Mamasa".

\section{B. Rumusan Masalah}

1. Bagaimanakah kapasitas perangkat desa dalam pengelolaan dana desa di Desa Osango Kecamatan Mamasa Kabupaten Mamasa?

2. Bagaimanakah akuntabilitas perangkat desa dalam pengelolaan dana desa di Desa Osango Kecamatan Mamasa Kabupaten Mamasa?

\section{Tujuan Penelitian}

1. Untuk mengetahui kapasitas perangkat desa dalam pengelolaan dana desa di Desa Osango Kecamatan Mamasa Kabupaten Mamasa.

2. Untuk mengetahui akuntabilitas perangkat desa dalam pengelolaan dana desa di Desa Osango Kecamatan Mamasa Kabupaten Mamasa.

\section{Manfaat Penelitian}

1. Bagi Pemerintah, dapat menjadi suatu referensi maupun tinjauan secara nyata yang mendiskripsikan tingkat kinerja pemerintah untuk mewujudkan pemerintah yang good government dan good governance.

2. Bagi Pemerintah Desa Osango Kecamatan Mamasa Kabupaten Mamasa, dapat menjadi referensi bagi pegawai maupun pihak-pihak yang ada dalam Pemerintah Desa agar senantiasa bekerja secara transparan yang bersih dan berwibawa terutama dalam hal pengelolaan keuangan desa.

3. Bagi Masyarakat, penelitian ini dapat menjadi sumber data atau informasi terhadap masyarakat, khususnya masyarakat Desa Osango Kecamatan Mamasa Kabupaten Mamasa mengenai kapasitas dan pelaksanaan fungsi dari perangkat desa, khususnya dalam akuntabilitas pengelolaan keuangan desa dan faktor-faktor yang memengaruhinya.

\section{METODE PENELITIAN}

Metode penelitian yang digunakan dalam penelitian ini adalah metode deskriptif sehingga penelitian ini merupakan penelitian deskriptif. Pendekatan yang digunakan dalam penelitian ini adalah pendekatan kuantitatif yang didasari oleh filsafat positivisme yang menekankan fenomenafenomena objektif dan dikaji secara kuantitatif. Maksimalisasi objektivitas desain penelitian ini dilakukan dengan menggunakan angka-angka dan pengolahan statistik (Sukmadinata, 2012: 53).

Penelitian dilaksanakan di Desa Osango Kecamatan Mamasa Kabupaten Mamasa Provinsi Sulawesi Barat selama kurang lebih tiga bulan, yaitu pada bulan Februari 2020 sampai dengan bulan April 2020. Populasi dalam penelitian ini adalah serluruh perangkat desa di Desa Osango yang berjumlah 30 orang, terdiri dari Kepala Desa, Sekretaris Desa, Kepala Seksi 3 orang, Kepala Urusan 3 orang, Kepala Dusun 4 orang, Ketua RT 12 orang, Ketua, Sekretaris dan Anggota Badan 
Permusyawaratan Desa (BPD), serta Ketua, Sekretaris dan Anggota Lembaga Pemberdayaan Masyarakat (LPM). Metode pemilihan sampel yang digunakan adalah metode sensus atau sampling jenuh, yaitu seluruh anggota populasi diambil sebagai sampel penelitian. Sehingga sampel sebagai sumber data dalam penelitian ini berjumlah 30 orang.

Sumber data dalam penelitian ini adalah sumber data primer dan sumber data sekunder. Sumber data primernya adalah hasil jawaban responden pada kuesioner dan hasil jawaban responden pada wawancara yang dilakukan dalam penelitian ini. Sumber data sekundernya adalah buku-buku literatur, arsip-arsip, perundang-undangan, jurnal dan dokumen resmi yang berhubungan dengan masalah yang diteliti.

Metode yang digunakan dalam pengumpulan data adalah metode kuesioner (angket), wawancara, dan dokumentasi. Angket yang digunakan adalah angket tertutup dengan menggunakan skala Guttman, dimana skala pengukuran dengan tipe ini didapat jawaban tegas "Ya atau Tidak". Setiap kriteria diberikan skor sesuai dengan kondisi yang sesungguhnya terjadi pada organisasi, masyarakat, atau individu dengan tingkat: (1) Untuk jawaban "Ya" diberi skor 1 dan (2) Untuk jawaban "Tidak" diberi skor 0.

Wawancara (interview) dalam penelitian ini merupakan metode pengumpulan data melalui tanya jawab secara langsung dengan perangkat desa di Desa Osango yang menjadi responden penelitian ini. Wawancara dilakukan untuk mengumpulkan data tentang kapasitas perangkat desa dan akuntabilitas perangkat desa dalam pengelolaan dana desa di Desa Osango. Dokumentasi yang dilakukan bertujuan untuk mencatat kegiatan perangkat desa di Desa Osango dalam akuntabilitas pengelolaan dana desa, yakni data tentang pengelolaan keuangan desa mulai dari perencanaan, pelaksanaan, penatausahaan, pelaporan, sampai dengan pertanggung jawaban pada Desa Osango.

Teknik analisis data yang digunakan dalam penelitian ini adalah teknik analisis deskriptif. Data-data hasil kuesioner dianalisis dengan pendekatan kuantitatif. Bentuk statistik deskriptif yang dianalisis adalah penentuan frekuensi, persentase, dan penentuan rata-rata. Untuk mengetahui persentase jawaban tentang kapasitas perangkat desa dalam pengelolaan dana desa dan jawaban tentang akuntabilitas perangkat desa dalam pengelolaan dana desa berdasarkan jawaban pada kuesioner, digunakan rumus perhitungan skala Guttman sebagai berikut:

$$
\text { Persentase }=\frac{\text { Jumlah Rata-rata Jawaban "Ya" }}{\text { Jumlah Responden }} \times 100 \%
$$

Berdasarkan perhitungan dengan rumus di atas, maka kapasitas perangkat desa dan akuntabilitas perangkat desa dalam pengelolaan dana desa akan terlihat dalam persentase hasil analisis sebagai berikut:

1. $0 \%-59 \%=$ memiliki kapasitas atau akuntabilitas yang rendah.

2. $60 \%-69 \%=$ memiliki kapasitas atau akuntabilitas yang kurang.

3. $70 \%-79 \%=$ memiliki kapasitas atau akuntabilitas yang cukup.

4. $80 \%-89 \%=$ memiliki kapasitas atau akuntabilitas yang tinggi.

5. $90 \%-100 \%=$ memiliki kapasitas atau akuntabilitas sangat tinggi.

Data-data hasil wawancara dan dokumentasi dianalisis dengan pendekatan kualitatif pola interaktif yang dikembangkan oleh Miles dan Huberman bahwa aktivitas dalam analisis data kualitatif 
dilakukan secara interakatif dan berlangsung secara terus menerus sampai tuntas, sehingga datanya sudah jenuh. Aktivitas dalam analisis data yaitu data reduction (reduksi data), data display (penyajian data), dan conclusion drawing/verification (penarikan kesimpulan atau verifikasi (Sugiyono, 2015: 337).

\section{HASIL PENELITIAN DAN PEMBAHASAN}

\section{A. Karakteristik Umum Responden}

Karakteristik responden yang digunakan dalam penelitian ini terdiri dari 3 (tiga) kategori, yaitu karakteristik berdasarkan jenis kelamin, karateristik berdasarkan tingkat pendidikan terakhir, dan karateristik berdasarkan lama bekerja.

Karakteristik responden berdasarkan jenis kelamin dalam penelitian ini dibagi menjadi dua karakter, yaitu jenis kelamin laki-laki dan perempuan. Responden penelitian berjenis kelamin lakilaki berjumlah 26 orang dan responden berjenis kelamin perempuan sebanyak 4 orang sebagaimana dirinci dalam tabel 1.

Tabel 1.

Karakteristik Responden Berdasarkan Jenis Kelamin

\begin{tabular}{|c|c|c|c|}
\hline No & Jenis Kelamin & Jumlah & Persentase \\
\hline 1 & Laki-laki & 26 & 86,67 \\
\hline 2 & Perempuan & 4 & 13,33 \\
\hline & Jumlah & $\mathbf{3 0}$ & $\mathbf{1 0 0}$ \\
\hline
\end{tabular}

Sumber: Data primer diolah tahun 2020.

Berdasarkan data pada tabel 1 dapat diketahui bahwa jumlah responden berjenis kelamin laki-laki sebanyak 26 orang atau sebesar $86,67 \%$ dan responden berjenis kelamin perempuan sebanyak 4 orang dengan persentase sebesar $13,33 \%$.

Karakteristik responden penelitian berdasarkan tingkat pendidikan terakhir yang digunakan dibagi menjadi lima tingkatan, yaitu SD, SMP, SMA, S1, dan S2. Karakteristik responden berdasarkan tingkat pendidikan terakhir tersebut dapat dilihat pada tabel 2.

Tabel 2.

Karakteristik Responden Berdasarkan Tingkat Pendidikan Terakhir

\begin{tabular}{|c|c|c|c|}
\hline No & Tingkat Pendidikan Terakhir & Jumlah & Persentase (\%) \\
\hline 1 & S2 & - & 0,00 \\
\hline 2 & S1 & 3 & 10,00 \\
\hline 3 & SMA/Sederajat & 27 & 90,00 \\
\hline 4 & SMP/Sederajat & - & 0,00 \\
\hline 5 & SD/Sederajat & - & 0,00 \\
\hline & Jumlah & $\mathbf{3 0}$ & $\mathbf{1 0 0}$ \\
\hline
\end{tabular}

Sumber: Data primer diolah tahun 2020.

Berdasarkan data pada tabel 2 dapat diketahui bahwa jumlah responden dengan tingkat pendidikan terakhir S2 yaitu 0\%, jumlah responden dengan tingkat pendidikan S1 yaitu 3 orang atau sebesar 10\%, jumlah responden dengan tingkat pendidikan terakhir SMA/Sederajat yaitu 27 orang atau sebesar 90\%, jumlah responden dengan tingkat pendidikan terakhir SMP/Sederajat $0 \%$ dan 
jumlah responden dengan tingkat pendidikan terakhir SD 0\%. Hal tersebut menunjukkan bahwa jumlah responden yang paling banyak dalam penelitian ini adalah responden dengan tingkat pendidikan terakhir SMA/Sederajat yaitu 27 orang atau sebesar $90 \%$.

Karakteristik responden berdasarkan lama bekerja di Pemerintahan Desa Osango Kecamatan Mamasa dibagi menjadi tiga tingkatan, yaitu 1 sapai 5 tahun, 6 sampai 10 tahun, dan lebih dari 10 tahun. Berikut ini karakteristik responden berdasarkan lama bekerja:

Tabel 3.

Karakteristik Responden Berdasarkan Lama Bekerja

\begin{tabular}{|c|c|c|c|}
\hline No & Lama Bekerja & Jumlah & Persentase (\%) \\
\hline 1 & $1-5$ tahun & 11 & $36,67 \%$ \\
\hline 2 & 6-10 tahun & 7 & $23,33 \%$ \\
\hline 3 & Lebih dari 10 tahun & 12 & $40,00 \%$ \\
\hline \multicolumn{2}{|c|}{ Jumlah } & $\mathbf{3 0}$ & $\mathbf{1 0 0}$ \\
\hline
\end{tabular}

Sumber: Data primer diolah tahun 2020.

Tabel 3 memperlihatkan bahwa jumlah responden yang telah bekerja di Pemerintahan Desa Osango dengan lama bekerja antara 1 samapai 5 tahun adalah 11 orang atau sebesar $36,67 \%$, jumlah responden yang telah bekerja dengan lama bekerja antara 6 sampai 10 tahun sebanyak 7 orang atau sebesar $23,33 \%$, dan responden yang telah bekerja selama lebih dari 10 tahun sebanyak 12 orang atau sebesar $40 \%$. Hal tersebut menunjukkan bahwa jumlah responden yang paling banyak dalam penelitian ini adalah responden yang telah bekerja di Pemerintahan Desa Osango dengan lama bekerja lebih dari 10 tahun yaitu 12 orag atau sebesar 40\% dan antara 1 sampai 5 tahun yaitu 11 orag atau sebesar $36,67 \%$.

\section{B. Hasil Penelitian dan Pembahasan}

\section{Kapasitas Perangkat Desa dalam Pengelolaan Dana Desa di Desa Osango}

Pemimpin di dalam sebuah organisasi mempunyai peran, setiap pekerjaan membawa harapan bagaimana penanggung peran beprilaku. Fakta bahwa organisasi mengindetifikasikan pekerjaan yang harus dilakukan dan perilaku peran yang diinginkan yang berjalan seiring pekerjaan tersebut juga mengandung arti bahwa harapan mengenai peran penting dalam mengatur perilaku bawahan. Organisasi harus juga berusaha untuk mengembangkan sumber daya manusia mereka. Pelatihan dan pengembangan membuat pegawai dapat melaksanakan pekerjaan mereka saat ini secara efektif dan mempersiapkan pekerjaan di masa mendatang.

Desa dipimpin oleh seorang Kepala Desa. Dalam melaksanakan tugasnya, Kepala Desa dibantu oleh perangkat desa. Perangkat Desa terdiri atas sekretariat desa, pelaksana kewilayahah dan pelaksana teknis. Kapasitas perangkat desa dalam mengelola dana desa adalah kemampuan perangkat desa untuk melaksanakan fungsi-fungsi atau kewenangannya dalam mengelola dana desa untuk mencapai tujuan pengelolaan dana desa secara efektif dan efisien. Dalam hal ini perangkat desa harus memiliki kapasitas dalam mengelola dana desa, yaitu kapasitas perangkat desa dalam proses perencanaan penggunaan dana desa, perangkat desa memiliki kapasitas dalam memberikan masukan tentang rancangan APB Desa, kepada Kepala Desa dan/atau BPD dan perangkat desa memiliki kapasitas dalam proses pelaksanaan penggunaan ADD, perangkat desa bersama dengan Kasi 
memiliki kapasitas dalam menyusun $\mathrm{RAB}$, memfasilitasi proses pengadaan barang dan jasa, mengelola atau melaksanakan pekerjaan terkait kegiatan yang telah ditetapkan dalam Perdes tentang APB Desa, perangkat desa memiliki kapasitas dalam memberikan masukan terkait perubahan APB, perangkat desa memiliki kapasitas dalam proses penatausahaan penggunaan ADD, perangkat desa memiliki kapasitas dalam meminta informasi, memberikan masukan, melakukan audit partisipatif.

Kapasitas perangkat desa dalam mengelola dana desa sebagamana dipaparkan di atas, juga harus dimiliki perangkat desa di Desa Osango Kecamatan Mamasa Kabupaten Mamasa sebagai tempat penelitian ini. Hasil penelitian yang dilakukan peneliti untuk melihat kapasitas perangkat desa dalam mengelola dana desa di Desa Osango dapat dilihat pada tabel 4.

Tabel 4.

Distribusi dan Persentase Jawaban Responden terkait dengan Kapasitas

Perangkat Desa Osango

\begin{tabular}{|c|c|c|c|}
\hline $\begin{array}{c}\text { No } \\
\text { Pertanyaan }\end{array}$ & $\begin{array}{c}\text { Jawaban } \\
\text { Ya }\end{array}$ & $\begin{array}{c}\text { Jawaban } \\
\text { Tidak }\end{array}$ & $\begin{array}{c}\text { Jumlah } \\
\text { Responden }\end{array}$ \\
\hline 1 & 22 & 8 & 30 \\
\hline 2 & 21 & 9 & 30 \\
\hline 3 & 20 & 10 & 30 \\
\hline 4 & 21 & 9 & 30 \\
\hline 5 & 22 & 8 & 30 \\
\hline 6 & 21 & 9 & 30 \\
\hline 7 & 24 & 6 & 30 \\
\hline 8 & 19 & 11 & 30 \\
\hline 9 & 21 & 9 & 30 \\
\hline 10 & 20 & 10 & 30 \\
\hline Total & $\mathbf{2 1 1}$ & 89 & $\mathbf{3 0}$ \\
\hline Rata-rata & $\mathbf{2 1 , 1}$ & $\mathbf{8 , 9}$ & $\mathbf{3 0}$ \\
\hline
\end{tabular}

Sumber: Data primer diolah tahun 2020.

Persentase Kapasitas Perangkat Desa Osango $=21,1 / 30 \times 100 \%=70,33 \%$

Data pada tabel 4 memperlihatkan bahwa distribusi dan perhitungan persentase jawaban respomden dari hasil kuesioner yang telah dibagikan dengan jumlah pertanyaan sebanyak 10 pertanyaan terkait dengan kapasitas perangkat desa dan jumlah responden sebanyak 30 responden, menunjukkan ada 211 total jawaban ya atau rata-rata jawaban ya sebanyak 21,1 dan ada 89 total jawaban tidak atau rata-rata jawaban tidak sebanyak 8,9.

Dari jawaban responden tersebut, tingkat persentase kapasitas perangkat desa dalam mengelola dana desa di Desa Osango mencapai 70,33\%. Dengan demikian, tingkat persentase dari kapasitas perangkat desa dalam mengelola dana desa di Desa Osango dikategorikan memiliki kapasitas yang cukup tinggi (kategori sedang). Hal ini berarti bahwa perangkat desa di Desa Osango telah memiliki kapasitas yang cukup tinggi atau berkategori sedang dalam pengelolaan dana desa di Desa Osango. Hal ini dapat dilihat dari proses perencanaan penggunaan dana desa, dimana perangkat desa di Desa Osango cukup mampu memberikan masukan tentang rancangan Anggaran Pendapatan dan Belanja (APB) Desa kepada Kepala Desa dan/atau BPD, perangkat desa cukup mampu melakukan proses pelaksanaan penggunaan Anggaran Dana Desa (ADD), perangkat desa bersama 
dengan Kasi cukup mampu menyusun Rencana Anggaran Biaya (RAB), cukup mampu memfasilitasi proses pengadaan barang dan jasa, cukup mampu mengelola atau melaksanakan pekerjaan terkait kegiatan yang telah ditetapkan dalam Perdes tentang APB Desa, perangkat desa cukup mampu memberikan masukan terkait perubahan APB, perangkat desa cukup mampu terlibat dalam proses penatausahaan penggunaan ADD, perangkat desa cukup mampu memberikan masukan dan cukup mampu melakukan audit partisipatif.

Berdasarkan hasil penelitian dimana kapasitas perangkat desa dalam pengelolaan dana desa di Desa Osango yang masih berada pada kategori cukup ini mungkin disebabkan kondisi kapasitas perangkat desa di Desa Osango yang kurang mendukung baik dari segi kualitas maupun kuantitas. Dari sisi kualifikasi, sebagian besar perangkat desa di Desa Osango tidak memiliki latar belakang pendidikan akuntansi dan hal ini terlihat dari data demografi responden. Kelemahan yang ada diimbangi dengan mengikutsertakan perangkat desa dalam pelatihan-pelatihan yang berhubungan dengan akuntansi dan pengelolaan keuangan seperti pelatihan perpajakan, pelatihan bendahara, pelatihan SIMDA keuangan, dan pelatihan penatausahaan pengelolaan keuangan desa.

\section{Akuntabilitas Perangkat Desa dalam Pengelolaan Dana Desa di Desa Osango}

Akuntabilitas adalah proses penganggaran dari perencanaan, pelaksanaan, penatausahaan, pelaporan dan pertanggungjawaban. Sehingga indikator yang telah diukur pada penelitian ini terkait dengan akuntabilitas perangkat desa dalam pengelolaan dana desa di Desa Osango dapat dijelaskan sebagai berikut.

a. Perencanaan

Pemerintah desa di Desa Osango Kecamatan Mamasa Kabupaten Mamasa menyusun perencanaan pembangunan desa sesuai dengan kewenangannya dengan mengacu pada perencanaan pembangunan Kabupaten Mamasa. Rencana pembangunan desa di Desa Osango disusun untuk menjamin keterkaitan dan kosistensi antara perencanaan, penganggaran, pelaksanaan, dan pengawasan. Untuk melihat tingkat akuntabilitas perencanaan dana desa di Desa Osango dapat dilihat pada tabel 5.

Tabel 5.

Distribusi dan Persentase Jawaban Akuntabilitas Perencanaan Dana Desa

\begin{tabular}{|c|c|c|c|}
\hline $\begin{array}{c}\text { No } \\
\text { Pertanyaan }\end{array}$ & $\begin{array}{c}\text { Jawaban } \\
\text { Ya }\end{array}$ & $\begin{array}{c}\text { Jawaban } \\
\text { Tidak }\end{array}$ & $\begin{array}{c}\text { Jumlah } \\
\text { Responden }\end{array}$ \\
\hline 1 & 23 & 7 & 30 \\
\hline 2 & 22 & 8 & 30 \\
\hline 3 & 21 & 9 & 30 \\
\hline 4 & 21 & 9 & 30 \\
\hline 5 & 21 & 9 & 30 \\
\hline 6 & 19 & 11 & 30 \\
\hline Total & $\mathbf{1 2 7}$ & $\mathbf{5 3}$ & $\mathbf{3 0}$ \\
\hline Rata-rata & $\mathbf{2 1 , 1 7}$ & $\mathbf{8 , 8 3}$ & $\mathbf{3 0}$ \\
\hline
\end{tabular}

Sumber: Data primer diolah tahun 2020.

Persentase Akuntabilitas Perencanaan $=21,17 / 30 \times 100 \%=70,57 \%$

Data pada tabel 5 memperlihatkan bahwa distribusi dan perhitungan persentase jawaban responden terkait dengan akuntabilitas perencanaan pengelolaan dana desa di Desa Osango dari hasil 
kuesioner dengan jumlah pertanyaan sebanyak 6 pertanyaan dan jumlah responden sebanyak 30 responden, menunjukkan ada 127 total jawaban ya atau rata-rata jawaban ya sebanyak 21,17 dan 53 total jawaban tidak atau rata-rata jawaban tidak sebanyak 8,83 .

Dari jawaban responden tersebut, tingkat persentase terhadap akuntabilitas perencanaan pengelolaan dana desa di Desa Osango mencapai 70,57\%. Dengan demikian, tingkat persentase akuntabilitas perencanaan pengelolaan dana desa di Desa Osango dapat dikategorikan cukup akuntabel, dalam hal ini perangkat desa di Desa Osango cukup akuntabel dalam melaksankan perencanaan pengelolaan dana desa di Desa Osango. Hal ini berarti perangkat desa di Desa Osango Kecamatan Mamasa Kabupaten Mamasa dalam melaksanakan perencanaan pengalokasian dana desa dikategorikan cukup akuntabel.

Dengan demikian, akuntabilitas perangkat desa di Desa Osango dalam melaksanakan perencanaan pengalokasian dana desa sudah dapat dikatakan sesuai dengan Permendagri No.113 Tahun 2014 tentang Pengelolaan Keuangan Desa. Sebagaimana diungkapkan Marten Arruansilomba, SE (Kepala Desa Osango) bahwa:

"Akuntabilitas perangkat desa di Desa Osango dalam melaksanakan perencanaan pengalokasian dana desa dapat dikatakan sudah sesuai dengan Permendagri No.113 Tahun 2014 tentang Pengelolaan Keuangan Desa. Proses perencanaan pengelolaan dana desa pada Desa Osango ini diawali dengan penyusunan APBDes. Namun sebelum itu, dilakukan terlebih dahulu Musyawarah Dusun. Hal ini bertujuan untuk menyaring aspirasi masyarakat di tingkat dusun terkait dengan konsep pembangunan yang diinginkan oleh masyarakat dusun. Poin-poin hasil kesepakatan dalam Musyawarah Dusun (Musdus) tersebut akan dijadikan data yang akan dibahas pada Musyawarah Desa (Musdes)" (Hasil Wawancara, 14 Maret 2020).

Musyawarah Desa (Musdes) dilakukan untuk mengsinkronisasikan hasil kesepakatan dalam Musdus serta membahas tentang arah dan rencana prioritas pembangunan desa selama 5 tahun dan sumber pembiayaan kegiatan pembangunan desa dan pelaksanaan pembangunan desa. Hasil kesepakatan dalam musyawarah desa akan dituangkan dalam berita acara dan menjadi landasan penyusunan Rencana Pembangunan Jangka Menengah Desa (RPJMDes). Selanjutnya, kepala desa akan menyelenggarakan Musyawarah Perencanaan Pembangunan (Musrembang) Desa. Sebagaimana diungkapkan Ketua BPD Desa Osango dalam wawancara sebagai berikut:

"Musdes yang dilakukan bertujuan untuk mengsinkronisasikan hasil kesepakatan dalam Musdus serta membahas tentang arah dan rencana prioritas pembangunan desa selama 5 tahun dan sumber pembiayaan kegiatan pembangunan desa dan pelaksanaan pembangunan desa. Selanjutnya hasil kesepakatan dalam musyawarah desa akan dituangkan dalam berita acara dan menjadi landasan penyusunan RPJMDes. Kemudian kepala desa akan menyelenggarakan Musrembang Desa" (Hasil Wawancara, 22 Maret 2020).

Berdasarkan hasil wawancara tersebut, Musrembang Desa diadakan untuk membahas dan menyepakati rancangan RPJMDes serta menyepakati prioritas kebutuhan atau kegiatan desa yang akan menjadi bahan penyusunan Rencana Kerja Pembangunan Desa (RKPDes).

Lebih lanjut Ketua BPD Desa Osango memaparkan dalam wawancara sebagai berikut:

"Menurut pendapat dan pengamatan saya bahwa RKPDes merupakan penjabaran dari Rencana Pembangunan Jangka Menengah Desa untukjangka waktu 1 (satu) tahun. RKPDes yang telah disusun ini akan menjadi dasar dalam penetapan Anggaran Pendapatan dan 
Belanja Desa (APBDes) tetapi sebelumnya sekretaris desa menyusun rancangan peraturan desa tentang APBDes tersebut untuk disampaikan kepada Kepala Desa" (Hasil Wawancara, 22 Maret 2020).

Dengan demikian, peraturan desa tentang APBDes akan disepakati oleh Kepala Desa bersama BPD. Kemudian Peraturan Desa tersebut disampaikan kepada bupati melalui camat untuk dievaluasi. Hasil evaluasi tersebut akan ditindaklanjuti oleh Kepala Desa. APBDes yang telah ditetapkan dengan peraturan desa akan menjamin kepastian dari pelaksanaan program kegiatan. Dalam hal ini pemerintah desa akan melaksanakan program kegiatan sesuai dengan apa yang telah ditetapkan dalam APBDes, baik dari jenis program kegiatan maupun jumlah anggaran yang akan digunakan. Penetapan APBDes dalam peraturan desa merupakan tahap akhir dalam proses perencanaan.

b. Pelaksanaan

Dalam pelaksanaan anggaran desa yang sudah ditetapkan sebelumnya timbul transaksi penerimaan dan pengeluaran dana desa. Semua penerimaan dan pengeluaran dana desa dalam rangka pelaksanaan kewenangan desa dilaksanakan melalui rekening kas desa. Semua penerimaan dan pengeluaran desa harus didukung oleh bukti yang lengkap dan sah (Sujarweni, 2015: 19).

Hasil yang diperoleh dalam penelitian ini terkait dengan akuntabilitas pelaksanaan dana desa di Desa Osango Kecamatan Mamasa Kabupaten Mamasa dapat dilihat pada tabel 6.

Tabel 6.

Distribusi dan Persentase Jawaban atas Akuntabilitas Pelaksanaan Dana Desa

\begin{tabular}{|c|c|c|c|}
\hline $\begin{array}{c}\text { No } \\
\text { Pertanyaan }\end{array}$ & $\begin{array}{c}\text { Jawaban } \\
\text { Ya }\end{array}$ & $\begin{array}{c}\text { Jawaban } \\
\text { Tidak }\end{array}$ & $\begin{array}{c}\text { Jumlah } \\
\text { Responden }\end{array}$ \\
\hline 1 & 23 & 7 & 30 \\
\hline 2 & 20 & 10 & 30 \\
\hline 3 & 21 & 9 & 30 \\
\hline 4 & 21 & 9 & 30 \\
\hline 5 & 21 & 9 & 30 \\
\hline 6 & 21 & 9 & 30 \\
\hline 7 & 20 & 10 & 30 \\
\hline 8 & 20 & 10 & 30 \\
\hline 9 & 22 & 8 & 30 \\
\hline 10 & 21 & 9 & 30 \\
\hline 11 & 22 & 8 & 30 \\
\hline 12 & 21 & 9 & 30 \\
\hline 13 & 21 & 9 & 30 \\
\hline Total & $\mathbf{2 7 4}$ & $\mathbf{1 1 6}$ & $\mathbf{3 0}$ \\
\hline Rata-rata & $\mathbf{2 1 , 0 8}$ & $\mathbf{8 9}$ & $\mathbf{3 0}$ \\
\hline
\end{tabular}

Sumber: Data primer diolah tahun 2020.

Persentase Akuntabilitas Pelaksanaan Dana Desa $=21,08 / 30 \times 100 \%=70,27 \%$

Data pada tabel 6 memperlihatkan bahwa distribusi dan perhitungan persentase jawaban akuntabilitas pelaksanaan dana desa di Desa Osango dari hasil kuesioner dengan jumlah pertanyaan sebanyak 13 pertanyaan dan jumlah responden 30 orang, menunjukkan ada 274 total jawaban ya atau 
rata-rata jawaban ya sebanyak 21,08 dan 116 total jawaban tidak atau rata-rata jawaban tidak sebanyak 8,92 .

Dari jawaban responden tersebut, tingkat persentase akuntabilitas pelaksanaan dana desa di Desa Osango mencapai $70,27 \%$. Hal ini berarti perangkat desa dalam melaksanakan rencana pengalokasian dana desa di Desa Osango sudah cukup akuntabel. Dengan demikian, tingkat persentase akuntabilitas pelaksanaan dana desa di Desa Osango dikatakan cukup sesuai atau cukup akuntabel, dalam hal ini perangkat desa di Desa Osango Kecamatan Mamasa Kabupaten Mamasa cukup akuntabel atau cukup mampu melaksanakan program yang telah direncanakan secara efektif dan transparan.

Dengan demikian, akuntabilitas perangkat desa dalam melaksanakan rencana pengalokasian dana desa di Desa Osango Kecamatan Mamasa Kabupaten Mamasa sudah dapat dikatakan sesuai dengan Permendagri No.113 Tahun 2014 Tentang Pengelolaan Keuangan Desa.

Pelaksanaan pengelolaan dana desa merupakan implementasi atau eksekusi dari APBDes. Termasuk dalam pelaksanaan proses pengadaan barang dan jasa serta proses pembayaran. Pelaksanaan pengelolaan keuangan pada Desa Osango dilakukan setelah APBDes ditetapkan dalam bentuk peraturan desa. Dalam melaksanakan pengelolaan dana desa, Pemerintah Desa Osango berpedoman pada APBDes yang telah ditetapkan. Sebagaimana diungkapkan Ketua BPD Desa Osango dalam wawancara sebagai berikut:

"Menurut yang saya pahami bahwa pelaksanaan pengelolaan dana desa merupakan implementasi dari Anggaran Pendapatan dan Belanja Desa. Ya..., termasuk dalam pelaksanaan proses pengadaan barang dan jasa serta proses pembayaran. Demikian pula pelaksanaan pengelolaan keuangan di Desa Osango dilakukan setelah APBDes ditetapkan dalam bentuk peraturan desa dan dalam melaksanakannya, Pemerintah Desa Osango berpedoman pada APBDes yang telah ditetapkan" (Hasil Wawancara, 22 Maret 2020)

Sementara Marten Lantho Tiboyong (Sekretaris Desa Osango) mengungkapkan dalam wawancara bahwa:

"Hal pertama yang dilakukan dalam pelaksanaan pengelolaan dana desa di Desa Osango setelah APBDesa ditetapkan adalah mengajukan pendanaan untuk melaksanakan kegiatan. Pengajuan dana harus disertai dengan dokumen seperti RAB. RAB ini terlebih dahulu diverifikasi oleh Sekretaris Desa dan disahkan oleh Kepala Desa. RAB ini menjadi dasar bagi pelaksana kegiatan untuk melakukan tindakan pengeluaran atas beban anggaran belanja kegiatan" (Hasil Wawancara, 22 Maret 2020).

Dengan demikian, langkah awal yang dilakukan dalam pelaksanaan pengelolaan dana desa di Desa Osango setelah APBDesa ditetapkan adalah mengajukan pendanaan untuk melaksanakan kegiatan yang dilakukan oleh pelaksana kegiatan. Pengajuan dana tersebut harus disertai dengan dokumen antara lain RAB yang terlebih dahulu diverifikasi oleh Sekretaris Desa dan disahkan oleh Kepala Desa. RAB kegiatan ini menjadi dasar bagi pelaksana kegiatan untuk melakukan tindakan pengeluaran atas beban anggaran belanja kegiatan.

Kaur Keuangan Desa melakukan pembayaran berdasarkan RAB yang telah diverifikasi dan disahkan. Mekanisme pembayaran yang dilakukan oleh Kaur Keuangan Desa di Desa Osango dilaksanakan dengan dua cara. Pertama, Kaur Keuangan Desa melakukan pembayaran tanpa melalui 
panjar. Kedua, pembayaran melalui panjar terlebih dahulu kepada Pelaksana Kegiatan. Sebagaimana diungkapkan Marten Arruansilomba, SE (Kepala Desa Osango) dalam wawancara sebagai berikut:

"Yang berjalan selama ini di Desa Osango bahwa Kaur Keuangan Desa melakukan pembayaran berdasarkan RAB yang telah diverifikasi oleh Sekretaris Desa dan disahkan oleh Kepala Desa. Sementara mekanisme pembayaran yang dilakukan oleh Kaur Keuangan Desa dilaksanakan dengan dua cara, yaitu pembayaran tanpa melalui panjar atau pembayaran melalui panjar terlebih dahulu kepada Pelaksana Kegiatan" (Hasil Wawancara, 14 Maret 2020).

Pembayaran secara langsung oleh Kaur Keuangan Desa tanpa panjar kepada pihak ketiga dilakukan melalui uang kas. Jenis pembayaran yang dilakukan oleh Kaur Keuangan Desa secara langsung tanpa panjar yaitu pengeluaran yang bersifat rutin, seperti pengeluaran untuk keperluan pembayaran penghasilan tetap dan tunjangan, operasional pemeliharaan perkantoran, dan operasional BPD. Sedangkan mekanisme pembayaran melalui panjar kepada pelaksana kegiatan hanya dapat dilakukan oleh Kaur Keuangan Desa apabila memenuhi kondisi yang dipersyaratkan seperti batasan maksimal jumlah uang yang dapat dibayarkan secara kas kepada pihak ketiga. Hal ini diperlukan sebagai pengendalian agar jangan sampai pelaksana kegiatan memegang uang dalam jumlah besar yang tentunya memiliki resiko kehilangan, dan lain-lain.

Marthen (Kaur Keuangan Desa Osango Kecamatan Mamasa Kabupaten Mamasa) dalam wawancara mengatakan bahwa:

"Semua penerimaan dan pengeluaran harus didukung dengan bukti yang lengkap dan sah.

Bukti transaksi tersebut adalah dokumen pendukung yang berisi data transaksi yang dibuat setelah melakukan transaksi untuk kebutuhan pencatatan keuangan. Di dalam suatu bukti transaksi minimal memuat data pihak yang mengeluarkan atau yang membuat" (Hasil Wawancara, 24 Maret 2020).

\section{c. Penatausahaan}

Penatausahaan merupakan kegiatan pencatatan yang khususnya dilakukan oleh bendahara desa. Media penatausahaan berupa buku kas umum, buku pajak, buku bank serta setiap bulan membuat laporan pertanggungjawaban Kaur Keuangan Desa. Akuntabilitas penatausahaan dana desa di Desa Osango dapat dilihat pada tabel 7.

Tabel 7.

Distribusi dan Persentase Jawaban atas Akuntabilitas Penatausahaan Dana Desa

\begin{tabular}{|c|c|c|c|}
\hline $\begin{array}{c}\text { No } \\
\text { Pertanyaan }\end{array}$ & $\begin{array}{c}\text { Jawaban } \\
\text { Ya }\end{array}$ & $\begin{array}{c}\text { Jawaban } \\
\text { Tidak }\end{array}$ & Jumlah \\
\hline 1 & 22 & 8 & 30 \\
\hline 2 & 21 & 9 & 30 \\
\hline 3 & 21 & 9 & 30 \\
\hline Total & $\mathbf{6 4}$ & $\mathbf{2 6}$ & $\mathbf{3 0}$ \\
\hline Rata-rata & $\mathbf{2 1 , 3 3}$ & $\mathbf{8 . 6 7}$ & $\mathbf{3 0}$ \\
\hline
\end{tabular}

Sumber: Data primer diolah tahun 2020.

Persentase Akuntabilitas Penatausahaan Dana Desa $=21,33 / 30 \times 100 \%=71,1 \%$

Data pada tabel 7 memperlihatkan bahwa distribusi dan perhitungan persentase jawaban responden terkait dengan akuntabilitas penatausahaan dana desa di Desa Osango dari hasil kuesioner 
dengan jumlah pertanyaan sebanyak 3 pertanyaan dan jumlah responden 30 orang, menunjukkan ada 64 total jawaban ya atau rata-rata 21,33 dan ada 26 total jawaban tidak atau rata-rata 8,67.

Dari jawaban responden tersebut, tingkat persentase akuntabilitas penatausahaan dana desa di Desa Osango mencapai $71,1 \%$. Hal ini berarti perangkat desa dalam penatausahaan dana desa di Desa Osango sudah cukup akuntabel dan cukup mampu melaksanakan penatausahaan terhadap dana desa yang dikelola oleh Desa Osango secara efektif dan transparan untuk dipertanggungjawabkan. Artinya, perangkat desa dalam akuntabilitas penatausahaan dana desa di Desa Osango sudah dapat dikatakan cukup sesuai dengan Permendagri No.113 Tahun 2014 Tentang Pengelolaan Keuangan Desa.

Penatausahaan Keuangan Desa merupakan kegiatan pencatatan yang khususnya dilakukan oleh Kaur Keuangan Desa. Kaur Keuangan Desa Osango wajib melakukan pencatatan terhadap seluruh transaksi yang ada, berupa penerimaan dan pengeluaran kas dan harus melakukan pencatatan secara sistematis dan kronologis atas transaksi-transaksi keuangan yang terjadi. Kegiatan penatausahaan keuangan mempunyai fungsi pengendalian terhadap pelaksanaan APBDesa. Hasil dari penatausahaan adalah laporan yang dapat digunakan untuk pertanggungjawaban pengelolaan keuangan itu sendiri.

Penatausahaan penerimaan kas maupun pengeluaran kas yang dilakukan oleh Kaur Keuangan Desa Osango dilakukan dengan menggunakan Buku Kas, Buku Pajak dan Buku Bank. Semua penerimaan maupun pengeluaran tunai dibuatkan bukti transaksi berupa kuitansi dan dicatat dalam buku kas. Untuk penerimaan maupun pengeluaran yang berhubungan dengan pajak, Kaur Keuangan Desa mencatatnya dalam buku pajak yang tersedia. Sementara itu, buku bank dibuat oleh Kaur Keuangan Desa untuk membantu buku kas umum untuk mengetahui jumlah penerimaan dan pengeluaran kas di bank.

\section{d. Pelaporan}

Menurut Permendagri No 113 Tahun 2014 tentang Pengelolaan Keuangan Desa bahwa dalam melaksanakan tugas, kewenangan, hak dan kewajiban, kepala desa wajib melaporkan penggunaan pengelolaan dana desa. Akuntabilitas pelaporan dana desa di Desa Osango Kecamatan Mamasa Kabupaten Mamasa dapat dilihat pada tabel 8.

Tabel 8.

Distribusi dan Persentase Jawaban atas Akuntabilitas Pelaporan Dana Desa

\begin{tabular}{|c|c|c|c|}
\hline $\begin{array}{c}\text { No } \\
\text { Pertanyaan }\end{array}$ & $\begin{array}{c}\text { Jawaban } \\
\text { Ya }\end{array}$ & $\begin{array}{c}\text { Jawaban } \\
\text { Tidak }\end{array}$ & $\begin{array}{c}\text { Jumlah } \\
\text { Responden }\end{array}$ \\
\hline 1 & 22 & 8 & 30 \\
\hline 2 & 21 & 9 & 30 \\
\hline 3 & 22 & 8 & 30 \\
\hline 4 & 21 & 9 & 30 \\
\hline 5 & 21 & 9 & 30 \\
\hline 6 & 22 & 8 & 30 \\
\hline Total & $\mathbf{1 2 9}$ & $\mathbf{5 1}$ & $\mathbf{3 0}$ \\
\hline Rata-rata & $\mathbf{2 1 , 5}$ & $\mathbf{8 , 5}$ & $\mathbf{3 0}$ \\
\hline
\end{tabular}

Sumber: Data primer diolah tahun 2020.

Persentase Akuntabilitas Pelaporan Dana Desa $=21,5 / 30 \times 100 \%=71,67 \%$ 
Data pada tabel 8 memperlihatkan bahwa distribusi dan perhitungan persentase akuntabilitas pelaporan dana desa di Desa Osango dari hasil jawaban kuesioner dengan jumlah pertanyaan ada 6 dan jumlah responden 30 orang, menunjukkan ada 129 total jawaban ya atau rata-rata 21,5 dan ada 51 total jawaban tidak atau rata-rata 8,5 .

Dari jawaban responden tersebut, tingkat persentase akuntabilitas pelaoran dana desa di Desa Osango mencapai 71,67\%. Hal ini berarti perangkat desa dalam melakukan pelaporan penggunaan dana desa sudah cukup akuntabel, dalam hal ini perangkat desa yang diwakili kepala desa telah cukup akuntabel dalam melaporkan penggunaan dana desa kepada pihak-pihak yang berkepentingan. Dengan demikian, akuntabilitas perangkat desa dalam pelaporan penggunaan dana desa di Desa Osango sudah cukup sesuai dengan Permendagri No.113 Tahun 2014 Tentang Pengelolaan Keuangan Desa.

Pelaporan merupakan kegiatan yang dilakukan untuk menyampaikan hal-hal yang berhubungan dengan hasil pekerjaan yang telah dilakukan selama satu periode tertentu sebagai bentuk pelaksanaan tanggungjawab atas tugas dan wewenang yang diberikan. Pelaporan keuangan menjadi sebuah tolak ukur mengenai transparansi yang dilakukan oleh pemerintah Desa Osango dalam hal pengelolaan dana desa. Oleh karena itu, pelaporan pengelolaan keuangan desa menjadi kewajiban Pemerintah Desa Osango sebagai bagian yang tidak terpisahkan dari penyelenggaraan pemerintahan desa.

Pada tahap pelaporan, Pemerintah Desa Osango menyusun Laporan Realisasi Penggunaan Dana Desa dari tahap I sampai dengan tahap III serta Laporan Realisasi Pelaksanaan Anggaran Pendapatan dan Belanja Desa (APBDes) selama tahun Anggaran. Laporan Realiasasi Tahap I (satu) memberikan informasi tentang penggunaan dana desa yang diperoleh pada tahap I (satu) bulan April 2019 sebesar Rp 700.502.986. Laporan Realisasi tahap II menyediakan informasi mengenai penggunaan dana desa yang diperoleh pada tahap II (dua) bulan Agustus 2019 sebesar Rp 700.502.986. Dan Laporan Realisasi Tahap III (tiga) memberikan informasi mengenai penggunaan dana desa yang diperoleh pada tahap III (tiga) bulan November2019 sebesar Rp 350.251.493.

Sementara Laporan Realisasi Pelaksanaan Anggaran Pendapatan Belanja Desa (APBDes) merupakan Laporan mengenai penggunaan anggaran desa secara keseluruhan selama tahun anggaran mulai dari Dana Desa, Alokasi Dana Desa sampai Block Grand dengan dana sebesar Rp. 1.751.257.465.

e. Pertanggungjawaban

Setelah melaporkan penggunaan dana desa, Kepala Desa Osango sebagai wakil dari Perangkat Desa Osango wajib mempertanggungjawabkan hasil dari laporan penggunaan dana desa yang telah dibuat. Adapun akuntabilitas pertanggungjawaban penggunaan dana desa di Desa Osango dapat dilihat pada tabel 9.

Data pada tabel 9 memperlihatkan bahwa distribusi dan perhitungan persentase akuntabilitas pertanggungjawaban dana desa di Desa Osango dari hasil jawaban kuesioner dengan jumlah pertanyaan ada 3 pertanyaan dan jumlah responden 30 orang, menunjukkan ada 65 total jawaban ya atau rata-rata 21,67 dan ada 25 total jawaban tidak atau rata-rata 8,33.

Dari jawaban responden tersebut, persentase akuntabilitas pertanggungjawaban penggunaan dana desa di Desa Osango mencapai 72,23\%. Hal ini berarti perangkat desa di Desa Osango dalam 
melakukan pertanggungjawaban penggunaan dana desa dikatakan sudah cukup akuntabel, dalam hal ini perangkat Desa Osango yang diwakili Kepala Desa telah cukup akuntabel dalam melakukan pertanggungjawaban penggunaan dana desa kepada pihak-pihak yang berkepentingan. Dengan demikian, perangkat desa dalam melakukan pertanggung jawaban penggunaan dana desa di Desa Osango sudah cukup sesuai dengan Permendagri No.113 Tahun 2014 Tentang Pengelolaan Keuangan Desa.

Tabel 9.

Distribusi dan Persentase Jawaban atas Akuntabilitas Pertanggungjawaban Dana Desa

\begin{tabular}{|c|c|c|c|}
\hline $\begin{array}{c}\text { No } \\
\text { Pertanyaan }\end{array}$ & $\begin{array}{c}\text { Jawaban } \\
\text { Ya }\end{array}$ & $\begin{array}{c}\text { Jawaban } \\
\text { Tidak }\end{array}$ & $\begin{array}{c}\text { Jumlah } \\
\text { Responden }\end{array}$ \\
\hline 1 & 22 & 8 & 30 \\
\hline 2 & 22 & 8 & 30 \\
\hline 3 & 21 & 9 & 30 \\
\hline Total & $\mathbf{6 5}$ & $\mathbf{2 5}$ & $\mathbf{3 0}$ \\
\hline Rata-rata & $\mathbf{2 1 , 6 7}$ & $\mathbf{8 , 3 3}$ & $\mathbf{3 0}$ \\
\hline
\end{tabular}

Sumber: Data primer diolah tahun 2020.

Persentase Akuntabilitas Pertanggungjawaban Dana Desa $=21,67 / 30 \times 100 \%=72,23 \%$

Laporan Realisasi Pelaksanaan APBDes yang disampaikan oleh Pemerintah Desa Osango merupakan suatu bentuk akuntabilitas dalam pengelolaan dana desa. Dalam hal ini Laporan Pertanggungjawaban Realisasi Pelaksanaan APBDes menentukan bahwa setiap kegiatan dan hasil akhir kegiatan harus dapat dipertanggungjawabkan kepada masyarakat maupun kepada jajaran pemerintahan di atasnya sesuai peraturan perundang-undangan. Laporan Realisasi Pelaksanaan APBDes yang disajikan oleh Pemerintah Desa Osango berisi informasi tentang penggunaan anggaran desa secara keseluruhan selama tahun anggaran. Komponen-komponen yang disajikan dalam Laporan Realisasi APBDes yaitu pendapatan termasuk Dana Desa, Alokasi Dana Desa, dan Block Grand, belanja dan pembiayaan yang telah dilaksanakan selama tahun anggaran yang bersangkutan. Laporan Realisasi Pelaksanaan APBDes tersebut juga ditetapkan dengan peraturan desa karena dalam penyampaian laporan tersebut pemerintah desa diwajibkan untuk melampirkan peraturan desa terkait dengan pelaksanaan APBDes tersebut.

Secara umum tanggapan responden atas kapasitas perangkat desa dan akuntabilitas perangkat desa dalam pengelolaan dana desa di Desa Osango diperlihatkan pada tabel 10.

Tabel 10.

Tanggapan Responden Mengenai Kapasitas Perangkat Desa dan Akuntabilitas Perangkat Desa dalam Pengelolaan Dana Desa di Desa Osango

\begin{tabular}{|c|l|c|c|c|}
\hline No & $\begin{array}{c}\text { Kapasitas Perangkat Desa dan } \\
\text { Akuntabilitas Pengelolaan } \\
\text { Dana Desa }\end{array}$ & $\begin{array}{c}\text { Jumlah } \\
\text { Jawaban } \\
\text { Ya }\end{array}$ & $\begin{array}{c}\text { Jumlah } \\
\text { Jawaban } \\
\text { Tidak }\end{array}$ & $\begin{array}{c}\text { Total } \\
\text { Jawaban } \\
\text { Responden }\end{array}$ \\
\hline 1 & $\begin{array}{l}\text { Kapasitas Perangkat Desa dalam } \\
\text { Pengelolaan Dana Desa }\end{array}$ & 22 & 8 & 30 \\
\hline 2 & $\begin{array}{l}\text { Akuntabilitas Perangkat Desa } \\
\text { dalam Pengelolaan Dana Desa }\end{array}$ & 21 & 9 & 30 \\
\hline$\quad$ Total & $\mathbf{4 3}$ & $\mathbf{1 7}$ & $\mathbf{3 0}$ \\
\hline \multicolumn{2}{r}{ Rata-rata } & $\mathbf{2 1 , 5}$ & $\mathbf{8 , 5}$ & $\mathbf{3 0}$ \\
\hline
\end{tabular}


Sumber: Data primer diolah tahun 2020.

a. Rata-rata jumlah jawaban Ya $=21,5$

b. Total Jumlah Responden $=30$ orang

Persentase Jawaban Kuesioner $=21,5 / 30 \times 100 \%=71,67 \%$

Data pada tabel 10 memperlihatkan distribusi dan perhitungan persentase jawaban responden atas tanggapannya terhadap kapasitas perangkat desa dan akuntabilitas perangkat desa dalam pengelolaan dana desa di Desa Osango. Hasil tersebut menunjukkan bahwa kapasitas perangkat desa dalam pengelolaan dana desa di Desa Osango dapat dikatakan sudah memiliki kapasitas yang cukup tinggi atau berkategori sedang dan akuntabilitas perangkat desa dalam pengelolaan dana desa di Desa Osango dapat dikatakan sudah cukup akuntabel. Hal ini dibuktikan dari hasil perhitungan yang nilainya mencapai $71,67 \%$. Hal ini berarti bahwa perangkat desa di Desa Osango telah memiliki kapasitas yang cukup tinggi dalam pengelolaan dana desa dan cukup akuntabel dalam pengelolaan dana desa.

Dengan demikian, kapasitas perangkat desa dalam pengelolaan dana desa dan akuntabilitas perangkat desa dalam pengelolaan dana desa di Desa Osango telah cukup sesuai dengan Permendagri No. 113 Tahun 2014 Tentang Pengelolaan Keuangan Desa, yang dapat dilihat dari proses perencanaan, pelaksanaan, penatausahaan, pelaporan dan pertanggungjawaban yang dilakukan oleh perangkat Desa Osango.

Dalam proses perencanaan, perangkat desa di Desa Osango telah memiliki kapasitas yang cukup tinggi dan cukup akuntabel dalam menyusun perencanaan pembangunan desa dengan melakukan Musyawarah Dusun (Musdus) yang dilanjutkan pada Musyawarah Desa (Musdes) untuk membahas tentang arah dan rencana prioritas pembangunan desa selama 5 tahun serta sumber pembiayaan kegiatan pembangunan desa dan pelaksanaan pembangunan desa di Desa Osango. Sesuai hasil kesepakatan tersebut, perangkat desa membuat Rencana Pembangunan Jangka Menengah Desa (RPJMDes) yang selanjutnya akan dibahas dalam Musyawarah Perencanaan Pembangunan Desa (Musrenbangdes).

Kapasitas dan akuntabilitas perangkat desa dalam pelaksanaan pengelolaan dana desa di Desa Osango dapat dilihat dari proses pengadaan barang dan jasa dan proses pembayaran. Pengelolaan dana desa di Desa Osango dilakukan berdasarkan APBDes, pelaksana kegiatan mengajukan pendanaan untuk melaksanakan kegiatan dengan membawa Rencana Anggaran Biaya (RAB) yang akan dijadikan dasar bagi pelaksana kegiatan untuk melakukan tindakan pengeluaran atas beban anggaran belanja kegiatan.

Penatausahaan dilakukan perangkat desa yang diwakili oleh kepala urusan keuangan desa atau bendahara desa. Penatausahaan dana desa di Desa Osango dilakukan untuk mencatat semua transaksi yang ada, berupa penerimaan dan pengeluaran. Penatausahaan dana desa merupakan fungsi pengendalian terhadap pelaksanaan APBDes, hasil dari penatausahaan digunakan untuk pertanggungjawaban penggunaan dana desa. Penatausahaan penerimaan dan pengeluaran kas yang dilakukan kepala urusan keuangan desa di Desa Osango dilakukan dengan menggunakan buku kas umum, buku pembantu pajak dan buku bank.

Pelaporan dilakukan untuk menyampaikan hal-hal yang berhubungan dengan hasil pekerjaan yang dilakukan selama satu periode tertentu sebagai tanggungjawaban atas tugas dan wewenang yang 
diberikan. Perangkat desa di Desa Osango melakukan pelaporan dana desa mengenai penggunaan dana desa yang disusun dalam Laporan Realisasi Penggunaan Dana Desa dari tahap I, tahap II dan tahap III. Perangkat desa di Desa Osango melakukan pertanggungjawaban dana desa melalui Laporan Realisasi Pelaksanaan APBDes yang dilakukan oleh pemerintah desa, merupakan suatu bentuk akuntabilitas dalam mengelola dana desa. Laporan Pertanggungjawaban Realisasi Pelaksanaan APBDes menentukan bahwa setiap kegiatan dan hasil akhir harus dipertanggungjawabkan kepada pihak-pihak yang berkepentingan. Laporan Realisasi Pelaksanaan APBDes yang disajikan oleh Pemerintah Desa Osango berisi informasi tentang penggunaan anggaran desa secara keseluruhan selama tahun anggaran.

\section{PENUTUP}

\section{A. Simpulan}

1. Kapasitas perangkat desa dalam pengelolaan dana desa di Desa Osango Kecamatan Mamasa Kabupaten Mamasa mencapai persentase sebesar 70,33\%. Hal ini menunjukkan bahwa perangkat desa telah memiliki kapasitas yang cukup tinggi dalam pengelolaan dana desa. Ini dapat dilihat dari proses perencanaan penggunaan dana desa, dimana perangkat desa cukup mampu memberikan masukan tentang rancangan APBDesa kepada Kepala Desa dan/atau $\mathrm{BPD}$, perangkat desa cukup mampu dalam proses pelaksanaan penggunaan $\mathrm{ADD}$, perangkat desa bersama dengan Kasi cukup mampu menyusun RAB, cukup mampu memfasilitasi proses pengadaan barang dan jasa, cukup mampu mengelola atau melaksanakan pekerjaan terkait kegiatan yang telah ditetapkan dalam Perdes tentang APBDesa, perangkat desa cukup mampu memberikan masukan terkait perubahan APB, perangkat desa cukup mampu dalam proses penatausahaan penggunaan ADD, perangkat desa cukup mampu meminta informasi, memberikan masukan, dan cukup mampu melakukan audit partisipatif.

2. Akuntabilitas perangkat desa dalam pengelolaan dana desa di Desa Osango Kecamatan Mamasa Kabupaten Mamasa mencapai persentase sebesar 71,67\%. Hal ini berarti perangkat desa telah cukup akuntabel dalam pengelolaan dana desa dan dapat dikatakan bahwa akuntabilitas perangkat desa dalam pengelolaan dana desa di Desa Osango telah cukup sesuai dengan Permendagri No. 113 Tahun 2014 Tentang Pengelolaan Keuangan Desa. Hal ini dapat dilihat dari proses perencanaan, pelaksanaan, penatausahaan, pelaporan dan pertanggung jawaban yang dilakukan oleh perangkat Desa Osango yang semuanya cukup akuntabel.

\section{B. Saran}

1. Bagi Perangkat Desa Osango, penelitian ini diharapkan dapat dijadikan sebagai masukan dalam meningkatkan kapasitas perangkat desa dan akuntabilitas perangkat desa dalam pengelolaan dana desa. Perangkat Desa Osango harus lebih meningkatkan kapasitasnya dalam hal pengelolaan dana desa mengenai perencanaan, penggunaan, penatausahaan, pelaporan, dan pertanggung jawaban.

2. Bagi penelitian selanjutnya, diharapkan dapat memperluas lokasi penelitian di beberapa tempat dan menambah variabel penelitian yang akan diteliti sehingga dapat membandingkan dengan hasil penelitian yang ditemukan sebelumnya.

\section{DAFTAR PUSTAKA}


Arikunto, Suharsimi. Prosedur Penelitian Suatu Pendekatan Praktik. Jakarta: Rineka Cipta, 2013.

Azwar, Saifuddin. Metode Penelitian. Yogyakarta: Pustaka Pelajar, 2013.

Bastian, Indra. Akuntansi SektorPublik; Suatu Pengantar. Jakarta: Erlangga, 2010.

Hamzah, Ardi. Tata Kelola Pemerintahan Desa Menuju Desa Mandiri, Sejahtera, dan Partisipatoris. Surabaya: Pustaka Jawa Timur, 2015.

Hery. Akuntansi Dasar 1 \& 2. Jakarta: Gramedia Widia Sarana Indonesia, 2014.

Ikatan Akuntan Indonesia. Kompartemen ASP; Pedoman Asistensi Akuntansi Keuangan Desa. Jakarta: Ikatan Akuntan Indonesia, 2015.

Indriasari, Desi dan Ertambang Nahartyo. Pemgaruh Kapasitas SDM, Pemanfaatan Teknologi Informasi dan Pengendalian Intern Akuntansi terhadap Keterandalan dan Ketepatwaktuan Pelaporan Keuangan Pemerintah Daerah, Studi pada Pemerintah Kota Palembang dan Kabupaten Ogan Ilir. Jurnal Akuntansi, 2014.

Irma, Ade. Akuntabilitas Pengelolaan Alokasi Dana Desa (ADD) Dikecamatan Dolo Selatan Kabupaten Sigi. Jurnal Penelitia. Palu Sulawesi Tengah, 2015.

Kementerian Dalam Negeri. Permendagri No.113 Tahun 2014 Tentang Pengelolaan Keuangan Desa. Jakarta: Kementerian Dalam Negeri, 2014.

Kementrian Keuangan Republik Indonesia. Kebijakan Umum Dana Desa Berdasarkan UU No.6 Tahun 2014 dan PP No.60 Tahun 2014. Jakarta: Kementrian Keuangan Republik Indonesia, 2015.

LPJ Desa Osango. Laporan Pengelolaan Dana Desa Tahun 2019. Mamasa: Kantor Desa Osango, 2019.

Mardiasmo. Akuntansi Sektor Publik. Yogyakarta: Andi Offset, 2013.

Peraturan Pemerintah Nomor 24 Tahun 2005 tentang Standar Akuntansi Pemerintahan.

Renyowijoyo, Muindro. Akuntansi Sektor Publik; Organisasi Non Laba. Jakarta: Mitra Wacana Media, 2012.

Republik Indonesia. Undang-Undang No.6 Tahun 2014 tentang Desa. Jakarta: Kencana, 2015.

Republik Indonesia. Undang-Undang Nomor 17 Tahun 2003 tentang Keuangan Negara.

Republik Indonesia. Undang-Undang Nomor 23 Tahun 2014 tentang Pemerintahan Daerah.

Siregar, Syofian P. Statistik Deskriptif Untuk Penelitian. Jakarta: Raja Grafindo Persada, 2010.

Siswanto, B. Pengantar Manajemen. Jakarta: Bumi Aksara, 2010.

Sugiyono. Metode Penelitian Pendekatan Kuantitatif, Kualitatif, dan R \& D. Bandung: Alfabeta, 2015.

Sujarweni, V. Wiratna. Akuntansi Desa: Panduan Tata Kelola Keuangan Desa. Yogyakarta: Pustaka Baru, 2015.

Sukmadinata, Nana Syaodih. Metode Peneltian Pendidikan. Bandung: Remaja Rosdakarya, 2012.

Sumpeno, Wahjudin. Perencanaan Desa Terpadu. Edisi Kedua. Banda Aceh: Read, 2011. 